MATRIK: JURNAL MANAJEMEN, STRATEGI BISNIS DAN KEWIRAUSAHAAN

Homepage: https://ojs.unud.ac.id/index.php/imbk/index

Vol. 15 No. 2, Agustus (2021), 339-358

\title{
Peran Kemitraan Stakeholder Terhadap Kapabilitas Inovasi Dan Dampaknya Pada Kinerja Bisnis UKM Di Bali Dengan Mediasi Relational Quality
}

I Gusti Ayu Ketut Giantari ${ }^{1)}$, Ni Nyoman Kerti Yasa ${ }^{2)}$,

${ }^{1,2}$ Fakultas Ekonomi dan Bisnis Universitas Udayana, Bali, Indonesia email: ayugiantari@unud.ac.id

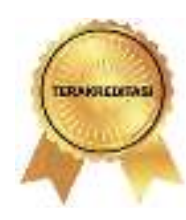

SINTA 2

DOI : https://doi.org/10.24843/MATRIK:JMBK.2021.v15.i02.p14

\begin{abstract}
ABSTRAK
Tujuan penelitian ini adalah untuk menjelaskan peran relational quality dalam memediasi pengaruh kemitraan pelanggan, kemitraan pemasok, dan kemitraan pesaing terhadap kapabilitas inovasi dan dampaknya pada kinerja bisnis. Metode pengumpulan data dalam penelitian ini adalah kuisioner. Populasi penelitian ini adalah pebisnis UKM di Bali. Besarnya sampel yang digunakan sebanyak 150 orang dengan metode purposive sampling. Teknik analisis yang digunakan adalah Path Analysis dengan menggunakan SEM berbasis PLS. Hasil penelitian menunjukkan bahwa kemitraan pelanggan berpengaruh positif dan signifikan terhadap relational quality. Kemitraan dengan pemasok juga berpengaruh positif dan signifikan terhadap relational quality dan kemitraan dengan pesaing berpengaruh positif dan signifikan terhadap relational quality. Selanjutnya relational quality berpengaruh positif dan signifikan terhadap kapabilitas inovasi. Relational quality mampu memediasi parsial secara signifikan pengaruh kemitraan pelanggan dan kemitraan pemasok terhadap kapabilitas inovasi. Namun dalam penelitian ditemukan bahwa kemitraan pesaing tidak memiliki pengaruh yang siginifikan terhadap kapabilitas inovasi, sehingga relational quality berperan sebagai mediasi sempurna (full mediation) antara kemitraan pesaing terhadap kapabilitas inovasi. Oleh karena itu penting bagi pebisnis UKM di Bali untuk meningkatkan kemitraan dengan pelanggan, pemasok, dan pesaing agar relational quality semakin baik sebagai dasar untuk meningkatkan kapabilitas inovasi yang berdampak pada peningkatan kinerja bisnis.
\end{abstract}

Kata kunci: Kemitraan; Relational Quality; Kapabilitas Inovasi; Kinerja Bisnis.

\section{The Role of Stakeholder Partnerships on Innovation Capability and Its Impact on SME Business Performance in Bali with Relational Quality Mediation}

\begin{abstract}
The purpose of this study is to explain the role of relational quality in mediating the effect of customer partnerships, supplier partnerships, and competitor partnerships on innovation capabilities and their impact on business performance. The method of data collection in this study is a questionnaire. The population of this research is SME businessmen in Bali. The size of the sample used is 150 people with purposive sampling method. The analytical technique used is Path Analysis using PLS-based SEM. The results showed that customer partnerships had a positive and significant effect on relational quality. Partnerships with suppliers also have a positive and significant effect on relational quality and partnerships with competitors have a positive and significant effect on relational quality. Relational quality has a positive and significant effect on innovation capability. Likewise, relational quality is able to partially significantly mediate the effect of customer partnerships and supplier partnerships on innovation capability. However, in the study, it was found that competitor partnerships did not have a significant effect on innovation capability, so that relational quality acted
\end{abstract}


as a perfect mediation (full mediation) between competitor partnerships on innovation capabilities. Therefore, it is important for SME businesses in Bali to improve partnerships with customers, suppliers, and competitors so that relational quality is getting better as a basis for increasing innovation capabilities that have an impact on improving business performance.

Keyword: Partnership;; Relational Quality; Innovation Capability; Business Performance.

\section{PENDAHULUAN}

Usaha Kecil Menengah (UKM) merupakan usaha dengan sumber daya yang relative kecil sampai menengah dan jumlahnya sangat banyak di suatu negara. UKM merupakan usaha yang juga memberi kontribusi besar kepada pertumbuhan ekonomi suatu negara, dengan cara menyerap tenaga kerja yang banyak sehingga mampu meingkatkan ketrampilan pekerja dan mengatasi pengangguran serta mengurangi tingkat kemiskisnan (Akinboade \& Kinfack, 2012; Yasa et al., 2013; Windapo et al., 2020). UKM perlu selalu diperhatikan dan diberdayakan agar kinerjanya bisa meningkat. UKM yang ada di Bali pada semua sektor harus diberdayakan, seperti UKM sektor kerajinan, sektor ritel, sektor manufaktur, dan sektor pertanian dan peternakan. Pada tiga tahun terakhir ini apalagi saat sekarang dengan terjadinya pandemic Covid-19, UKM pada semua sektor secara umum mengalami masalah, seperti: adanya penurunan capaian kinerja penjualannya, penurunan jumlah pelanggan, penurunan pangsa pasar, penurunan laba usaha, penurunan kualitas produk, penurunan kepuasan pelanggan, dan penurunan jumlah karyawan.

Penurunan kinerja bisnis yang dihadapi mencakup penurunan kinerja keuangan dan kinerja non keuangan. Penurunan kinerja keuangan antara lain, penurunan laba usaha, penurunan penjualan, dan penurunan jumlah transaksi bisnis. Penurunan kinerja non keuangan dapat dilihat dari adanya menurunnya kualitas barang, penurunan kepuasan konsumen, dan pengurangan jumlah karyawan. Capaian kinerja bisnis seperti ini dapat dipengaruhi oleh kemampuan atau kapabilitas inovasi yang mampu dilakukan perusahaan (Ferreira \& Coelho, 2020; Shafi, 2020). Kapabilitas inovasi dari UKM bisa dilihat dari kemampuannya selalu untuk mencoba ide baru, kemampuannya mencari metode operasi yang baru, kemampuannya selalu kreatif mencari metode baru, dan menjadi yang pertama di pasar (Shafi, 2020). Kapabilitas inovasi ini dapat dibangun berbasis kemitraan dengan para stakeholders-nya, seperti kemitraan dengan pelanggan, kemitraan dengan pemasok, dan kemitraan dengan pesaing. Kemitraan dengan pelanggan memang sangat menentukan kapabilitas inovasi. Melakukan kemitraan dengan pelanggan, maka UKM mendapat banyak informasi tentang keinginan pelanggan sebagai dasar untuk mengembangkan produk baru, mendesain produk yang lebih baik, dan mengembangkan teknologi baru sesuai keinginan pelanggan (Paula et al., 2019; Han et al., 2020). Semuanya itu mendorong peningkatan kapabilitas inovasi. Selanjutnya kemitraan dengan pemasok juga menentukan kapabilitas inovasi. Hal ini terungkap pada hasil penelitian yang dilakukan oleh beberapa peneliti, antara lain: Yang et al., (2018); Zacharia et al., (2019); Mokhtarzadeh et al., (2020), menunjukkan hasil bahwa kemitraan dengan pemasok memudahkan perusahaan untuk mendapatkan pemasok yang baik, kelancaran dalam pengiriman bahan baku, dan berbagi informasi tentang bahan baku. Selain bermitra dengan pelanggan dan pemasok, UKM juga perlu bermitra dengan pesaingnya. Melakukan kemitraan dengan pesaing juga bisa membangun kapabilitas inovasi yang semakin baik (Crick, 2019; 
Crick \& Crick, 2020), tetapi ada beberapa peneliti yang menunjukkan hasil yang sebaliknya, yaitu kemitraan dengan pesaing tidak mampu meningkatkan kapabilitas inovasi (Shafi, 2020).

Research gap tentang pengaruh kemitraan pesaing terhadap kapabilitas inovasi maka bisa dilengkapi dengan variabel pemediasi, yaitu relational quality. Penggunaan variabel relational quality sebagai variabel mediasi, antara lain karena: 1) relational quality yang mampu dibangun oleh pebisnis UKM seperti, memiliki komitmen dengan pelanggan, pemasok, dan pesaing menyebabkan kedekatan bisnis dengan stakeholders-nya, dan kedekatan hubungan dengan stakeholders tersebut bisa meningkatkan kapabilitas inovasi. Jika relational quality nya semakin baik maka perusahaan lebih mampu melakukan inovasi (Shou et al., 2017; Nguyen et al., 2019; Han et al., 2020). 2) Selain itu, relational quality juga dipengaruhi oleh intensitas kemitraan atau kemampuan kemitraan yang mampu dilakukan UKM baik kemitraan dengan pelanggan, pemasok, dan pesaing (Yu \& Huo, 2018; Paula et al., 2019; Crick \& Crick, 2020). Jika kemampuan kemitraan yang dibangun semakin baik maka relational quality nya juga semakin meningkat.

Berdasarkan latar belakang masalah, maka penelitian ini memiliki tujuan untuk menguji dan menjelaskan peran relational quality dalam memediasi kemitraan stakeholders (kemitraan pelanggan, kemitraan pemasok, dan kemitraan pesaing) terhadap kapabilitas inovasi dan dampaknya pada kinerja bisnis.

Kemitraan dengan stakeholders merupakan kemitraan yang dibangun oleh sebuah bisnis dalam rangka memperlancar berbagai aktifitas bisnisnya. Kemitraan ini tentunya berkaitan dengan pihak - pihak yang biasanya diajak bekerjasama dalam menjalankan aktifitas bisnisnya, antara lain bermitra dengan pelanggan, bermitra dengan pemasok, dan bermitra dengan pesaing.

Kemitraan yang sangat umum dan wajib dilakukan oleh perusahaan adalah menjalin kemitraan dengan pelanggan (Ngugi et al., 2010). Kemitraan dengan pelanggan merupakan kemitraan antara perusahaan dengan pelanggan dalam berbagai aktfitas, antara lain: berbagi informasi tentang kualitas produk, desain produk, teknologi, dan selera pelanggan secara menyeluruh (Shafi, 2020).

Kemitraan dengan pemasok merupakan salah satu strategi yang dijalankan oleh banyak bisnis dalam rangka unuk menjaga kelancaran penyediaan bahan baku dan mendapatkan bahan baku yang berkualitas dengan harga terbaik. Menurut Fawcett et al., (2015); Hudnurkar \& Rathod (2017), menyatakan bahwa hubungan yang dibangun dengan pemasoknya mendatangkan manfaat pada peningkatan kinerja bisnisnya.

Mangkunegara (2009) menyatakan bahwa kemitraan pesaing jaman sekarang ini semakin berkembang. Walaupun perusahaan pada umumnnya berkompetisi, tetapi di sisi lain perlu melakukan kemitraan dengan pesaingnya dalam beberapa aktifitas seperti: menyelesaikan jumlah pesanan yang masuk, membuka usaha baru, dan berbagi informasi tentang pelanggan dan pemasok (Lacam \& Salvetat, 2017; Crick, 2020).

Heimeriks \& Schreiner (2010) menyatakan bahwa relational quality merupakan kualitas hubungan antara dua atau lebih pihak yang bermitra. Relational quality bisa baik atau tidak baik bergantung dari kapabilitas hubungan yang dibangun berbasis keterbukaan yang menghasilkan komitmen dan kepercayaan (Crick \& Crick, 2020); Badawi \& Battor (2020); AlWugayan (2019).

Saunila \& Huko (2012), menyatakan bahwa kapabilitas inovasi adalah kemampuan untuk mengubah secara terus menerus pengetahuan dan ide menjadi produk, proses dan sistem baru untuk meraih keuntungan perusahaan. Perusahaan sebelumnya berfokus pada kualitas tinggi dan produk bernilai tambah. Saat ini, perusahaan mengikuti globalisasi dan mengadopsi inovasi terus menerus, yang menyoroti peran kunci dari kemampuan inovasi. Jadi, perusahaan 
bersaing untuk meningkatkan kapabilitas inovasi dalam rangka untuk mengembangkan produk inovatif Huhtala et al., (2014). Kapabilitas inovasi diukur dengan mengadaptasi empat item yang biasa digunakan dalam penelitian sebelumnya. Indikator dari variabel kapabilitas inovasi, adalah: perusahaan sering mencoba ide baru; perusahaan mencari cara baru untuk melakukan sesuatu; perusahaan kreatif dalam metode operasinya; dan perusahaan sering kali menjadi yang pertama memasarkan produk baru. Item ini telah divalidasi dan sudah banyak digunakan, termasuk Shafi (2020); .

Kinerja bisnis merupakan hasil akhir yang dituju oleh setiap perusahaan. Kinerja bisnis dapat dilihat dari beberapa perspektif. Ada yang melihat kinerja bisnis secara umum dan ada juga yang fokus pada bidang tertentu. Pada penelitian ini kinerja bisnis dilihat dari dua perspektif, yaitu: kinerja keuangan, kinerja non keuangan (Yu \& Huo, 2018; Panno, 2019).

Beberapa ahli menggunakan indikator yang berbeda untuk mengukur kinerja keuangan, seperti pertumbuhan laba, pendapatan, lapangan kerja, perkembangan bisnis (Tu et al., 2014), laba atas penjualan dan laba atas aset (Kantur, 2016). Penelitian ini fokus pada indikator yang menentukan keberhasilan dan pertumbuhan bisnis (misalnya peningkatan penjualan, transaksi penjualan, dan profitabilitas yang dipersepsikan (Martinez-Conesa et al., 2017; Shafi, 2020). Perusahaan diminta untuk menunjukkan sejauh mana persepsi mereka dengan peningkatan omset penjualan, jumlah transaksi penjualan dan capaian laba selama tiga tahun terakhir.

Para ahli menggunakan indikator pengukuran kinerja non keuangan seperti pencapaian tujuan profesional dan pribadi (Mendoza-ramırez \& Toledo-Lopez, 2014), kualitas layanan, kualitas produk, loyalitas karyawan, kepuasan karyawan (Kantur, 2016), dan kepuasan pelanggan (Haber \& Reichel, 2005). Pada penelitian ini, pengukuran kinerja non keuangan mengadopsi pengukuran dari Simon et al., (2015); Shafi (2020), yaitu peningkatan kualitas produk, kepuasan pelanggan, dan kepuasan karyawan.

Kinerja bisnis merupakan hasil akhir yang ingin dicapai oleh setiap pebisnis. Kinerja bisnis bisa ditunjukkan oleh capaian omset penjualan, jumlah laba, jumlah pelanggan, kepuasan pelanggan, loyalitas pelanggan, citra merek, perkembangan jumlah pegawai sehingga dapat dikatakan kinerja bisnis dapat dilihat dari beberapa persepektif, yaitu perspektif keuangan dan non keuangan. Capaian kinerja bisnis suatu perusahaan bisa dipengaruhi oleh kapabilitas inovasinya (Saunila \& Ukko, 2012). Kapabilitas inovasi bisa dibangun melalui kualitas hubungan stakeholders yang baik. Semakin baik kualitas hubungan yang dibangun dengan stakeholders yang ada maka dapat meningkatkan kapabilitas inovasi. Oleh karena itu, kualitas hubungan stakeholders perlu ditingkatkan terus dengan melakukan kemitraan dengan stakeholders utama, yaitu kemitraan dengan pelanggan, kemitraan dengan pemasok, dan kemitraan dengan pesaing (Shafi, 2020).

Ngugi et al., (2010) tentang kemitraan pelanggan mampu meningkatkan kapabilitas inovasi. Hasil ini juga diperkuat oleh hasil penelitian Shafi (2020), menemukan hasil bahwa kemitraan pelanggan berpengaruh positif dan signifikan terhadap kapabilitas inovasi. Pengaruh kemitraan pelanggan seperti kemitraan yang dibangun untuk meningkakan kualitas produk, meningkatkan desain produk, mengupdate teknologi dan berbagi informasi sangat penting untuk meningkatkan kapabilitas inovasi.

H1 : Kemitraan pelanggan berpengaruh positif dan signifikan terhadap kapabiltas inovasi.

Hasil penelitian sebelumnya yang dilakukan oleh Tu et al., (2014), tentang kemitraan pemasok mampu meningkatkan kapabilitas inovasi; dan Yang \& Shafi (2019), menemukan bahwa kemitraan pemasok berpengaruh positif terhadap kapabilitas inovasi. Hasil ini juga diperkuat oleh hasil penelitian Shafi (2020), menemukan hasil bahwa kemitraan pemasok berpengaruh positif dan signifikan terhadap kapabilitas inovasi. 
: Kemitraan pemasok berpengaruh positif dan signifikan terhadap kapabilitas inovasi.

Hasil penelitian sebelumnya yang dilakukan oleh Shafi (2020), yang menyatakan bahwa kemitraan pesaing tidak mampu meningkatkan kapabilitas inovasi. Hasil yang berlawanan diperoleh oleh Hoffmann et al., (2018), tentang kemitraan pesaing mampu meningkatkan kapabilitas inovasi. Dapat disimpulkan bahwa, kemitraan pesaing tidak memiliki pengaruh positif dan signifikan terhadap kapabilitas inovasi

H3 : Kemitraan pesaing berpengaruh positif dan signifikan terhadap kapabilitas inovasi.

Huo et al., (2014); Huo et al., (2016); Yu \& Huo (2018), yang menyatakan bahwa variabel kemitraan pelanggan berpengaruh positif dan signifikan terhadap relational quality. Hasil penelitian ini diperkuat oleh penelitian Yu \& Huo (2019), menemukan hasil variable kemitraan pelanggan berpengaruh positif dan signifikan terhadap relational quality sehingga dapat disimpulkan bahwa kemitraan pelanggan memiliki pengaruh yang positif dan signifikan terhadap relational quality

H4 : Kemitraan pelanggan berpengaruh positif dan signifikan terhadap relational quality.

Huo et al., (2016); Yu \& Huo (2018), yang menyatakan bahwa kemitraan pemasok memainkan peran penting dalam meningkatkan relational quality. Hasil penelitian tersebut juga diperkuat oleh hasil penelitian dari $\mathrm{Yu} \&$ Huo (2019), menemukan bahwa variabel kemitraan pemasok memiliki pengaruh positif dan signifikan terhadap variabel relational quality.

H5 : Kemitraan pemasok berpengaruh positif dan signifikan terhadap relational quality.

Crick (2019), menyatakan bahwa kemitraan pesaing mampu membuat relational quality dengan pesaing semakin baik; dan Bengtsson et al., (2016), menemukan bahwa kemitraan pesaing berpengaruh positif terhadap relational quality. Dapat disimpulkan bahwa, kemitraan pesaing memiliki pengaruh yang positif dan signifikan terhadap relational quality, hal ini berarti, dengan semakin baiknya kemitraan yang dijalin dengan pesaing maka kualitas hubungan dengan pesaing juga semakin baik.

H6 : Kemitraan pesaing berpengaruh positif dan signifikan terhadap relational quality.

Heimeriks \& Schreiner (2010), tentang relational quality mampu meningkatkan kapabilitas inovasi. Hasil ini juga diperkuat oleh hasil penelitian Ngugi et al., (2010); Nguyen et al., (2019), menemukan hasil bahwa relational quality berpengaruh positif dan signifikan terhadap kapabilitas inovasi. Pengaruh relational quality seperti komitmen terhadap pelanggan, memuaskan pelanggan, percaya dengan pelanggan, komitmen dengan pemasok, memuaskan pemasok, percaya dengan pemasok, komitmen dengan pesaing, dan percaya dengan pesaing sangat penting untuk meningkatkan kapabilitas inovasi. Dapat disimpulkan bahwa, relational quality memiliki pengaruh positif dan signifikan terhadap kapabilitas inovasi

H7 : Relational quality berpengaruh positif dan signifikan terhadap kapabilitas inovasi.

Bahta et al., (2021), tentang kapabilitas inovasi mampu meningkatkan kinerja bisnis. Saunila (2014) tentang kapabilitas inovasi mampu meningkatkan kinerja keuangan; Liao et al., (2020), menemukan bahwa kapabilitas inovasi berpengaruh positif dan signifikan terhadap kinerja bisnis termasuk kinerja keuangan. Dapat disimpulkan bahwa, kapabilitas inovasi memiliki pengaruh yang positif dan signifikan terhadap kinerja keuangan

H8 : Kapabilitas inovasi berpengaruh positif dan signifikan terhadap kinerja keuangan.

Kafetzopoulos \& Psomas (2015); Simon et al., (2015), tentang kapabilitas inovasi mampu meningkatkan kinerja non keuangan; dan Migdadi (2020), menemukan bahwa kapabilitas inovasi berpengaruh positif dan signifikan terhadap kinerja bisnis termasuk kinerja non keuangan. Dapat disimpulkan bahwa, kapabilitas inovasi memiliki pengaruh yang positif dan signifikan terhadap kinerja non keuangan

H9 : Kapabilitas inovasi berpengaruh positif dan signifikan terhadap kinerja non keuangan. 
Yusof et al., (2021) Fokus klien ditemukan memiliki efek mediasi parsial komplementer pada hubungan antara inovasi dan kinerja keuangan perusahaan dan bahwa inovasi secara independen mempengaruhi kinerja keuangan perusahaan dengan pengaruh yang lebih kuat di perusahaan arsitektur daripada di kontraktor perusahaan. Aydin (2021) Kemampuan teknologi memainkan peran mediasi dalam pengaruh orientasi pelanggan dan koordinasi interfungsional pada inovasi produk. Selain itu, koordinasi interfungsional mempengaruhi inovasi produk secara positif di perusahaan dengan intensitas teknologi rendah, sedangkan orientasi pelanggan secara positif mempengaruhi inovasi produk di perusahaan dengan intensitas teknologi sedang-tinggi. Berdasarkan penelitian terdahulu maka dirumuskan Relational quality mampu memediasi kemitraan pelanggan terhadap kapabilitas inovasi.

H10 : Relational quality mampu memediasi kemitraan pelanggan terhadap kapabilitas inovasi.

Byukusenge et al., (2021), Oleh karena itu, penelitian ini menambah pengetahuan baru dengan menyatakan bahwa inovasi terhadap kinerja bisnis merupakan mediator parsial dalam hubungan antara kompetensi manajerial dan kinerja bisnis UKM di Rwanda. Khalfallah et al., (2021) dampak langsung TQM yang tidak signifikan terhadap kinerja operasional. Namun, efek ini signifikan ketika dimediasi melalui inovasi produk dan inovasi proses. Lu et al., (2021) Berbagi informasi dan kemampuan inovasi memainkan peran mediasi antara ikatan lemah dan kuat dan kinerja pembiayaan UKM. Selain itu, kemampuan berbagi informasi dan inovasi saling melengkapi dan secara bersama-sama mempengaruhi kinerja pembiayaan UKM. Berdasarkan penelitian terdahulu maka dapat dirumuskan Relational quality mampu memediasi kemitraan pemasok terhadap kapabilitas inovasi

H11 : Relational quality mampu memediasi kemitraan pemasok terhadap kapabilitas inovasi.

Leite et al., (2018) menyatakan bahwa hubungan bisnis bertahan meskipun ada periode persaingan jika saling ketergantungan tinggi. Zhang et al., (2020) mengkonfirmasi bahwa keseimbangan hubungan antar perusahaan dapat menghasilkan kinerja perusahaan yang lebih unggul. Karakara \& Osabuohien (2020) pengeluaran perusahaan untuk penelitian dan pengembangan (R\&D), perusahaan memberi karyawannya kesempatan untuk mengembangkan ide-ide mereka dan ketika perusahaan bersaing dengan yang lain; semuanya berdampak positif pada keempat jenis inovasi. Berdasarkan penelitian terdahulu maka dapat dirumuskan Relational quality mampu memediasi pengaruh kemitraan pesaing terhadap kapabilitas inovasi.

H12 : Relational quality mampu memediasi pengaruh kemitraan pesaing terhadap kapabilitas inovasi.

\section{METODE PENELITIAN}

Jenis dari penelitian ini adalah kausalitas, artinya, penelitian ini bertujuan menguji hubungan kausalitas antara variabel kemitraan stakeholders, relational quality, kapabilitas inovasi, dan kinerja bisnis. Penelitian ini dilakukan pada UKM berbagai sektor di Bali. Besarnya sampel yang diambil sebesar 150 orang responden yang merupakan manajer atau pemilik UKM dengan teknik purposive sampling. Data dikumpulkan melalui penyebaran kuesioner sebagai instrument penelitian dengan menggunakan skala likert, yang diuji validitas dan reliabilitasnya pada sampel sebanyak 30 responden, yang hasilnya disajikan pada Tabel 1. Selanjutnya, setelah data terkumpul semuanya sebanyak 150 orang responden digunakan alat analisis, yaitu Path Analysis dengan menggunakan SEM-PLS. 


\section{HASIL DAN PEMBAHASAN}

Hasil pengujian validitas dan reliabilitas instrumen pada Tabel 1 menunjukkan bahwa seluruh variabel adalah valid karena nilai korelasi di atas 0,30 dan reliabel karena nilai Cronbach's Alpha di atas 0,6.

\section{Tabel 1. Hasil Pengujian Validitas dan Reliabilitas Instrumen}

\begin{tabular}{|c|c|c|c|}
\hline $\begin{array}{c}\text { Variabel } \\
\end{array}$ & Item & Korelasi r & Cronbach's Alpha $\alpha$ \\
\hline \multirow[t]{5}{*}{ Kemitraan pelanggan $(\mathrm{X} 1)$} & $\mathrm{X} 1$ & & 0,866 \\
\hline & $\mathrm{X} 1.1$ & 0,826 & \\
\hline & $\mathrm{X} 1.2$ & 0,850 & \\
\hline & $\mathrm{X} 1.3$ & 0,858 & \\
\hline & $\mathrm{X} 1.4$ & 0,872 & \\
\hline \multirow[t]{5}{*}{ Kemitraan pemasok (X2) } & $\mathrm{X} 2$ & & 0,804 \\
\hline & $\mathrm{X} 2.1$ & 0,813 & \\
\hline & $\mathrm{X} 2.1$ & 0,754 & \\
\hline & $\mathrm{X} 2.3$ & 0,836 & \\
\hline & $\mathrm{X} 2.4$ & 0,778 & \\
\hline \multirow[t]{4}{*}{ Kemitraan pesaing (X3) } & X3 & & 0,781 \\
\hline & $\mathrm{X} 3.1$ & 0,733 & \\
\hline & $\mathrm{X} 3.2$ & 0,897 & \\
\hline & $\mathrm{X} 3.3$ & 0,867 & \\
\hline \multirow[t]{10}{*}{ Relational quality (Y1) } & Y1 & & 0,867 \\
\hline & Y1.1 & 0,747 & \\
\hline & Y1.2 & 0,864 & \\
\hline & Y1.3 & 0,788 & \\
\hline & Y1.4 & 0,850 & \\
\hline & Y1.5 & 0,889 & \\
\hline & Y1.6 & 0,850 & \\
\hline & Y1.7 & 0,704 & \\
\hline & Y1.8 & 0,469 & \\
\hline & Y1.9 & 0,358 & \\
\hline \multirow[t]{4}{*}{ Kapabilitas inovasi (Y2) } & $\mathrm{Y} 2$ & & 0,846 \\
\hline & Y2.1 & 0,911 & \\
\hline & $\mathrm{Y} 2.2$ & 0,931 & \\
\hline & Y2.3 & 0,519 & \\
\hline \multirow[t]{4}{*}{ Kinerja Keuangan (Y3) } & Y3 & & 0,792 \\
\hline & Y3.1 & 0,927 & \\
\hline & Y3.2 & 0,686 & \\
\hline & Y3.3 & 0,911 & \\
\hline \multirow[t]{4}{*}{ Kinerja Non Keuangan (Y4) } & Y4 & & 0.726 \\
\hline & Y4.1 & 0,887 & \\
\hline & Y4.2 & 0,695 & \\
\hline & Y4.3 & 0,875 & \\
\hline
\end{tabular}

Sumber: data diolah, 2021

Berdasarkaan hasil penelitian, karakteristik responden responden laki-laki lebih banyak daripada responden perempuan dimana responden laki-laki sebanyak 60,00 persen sementara responden perempuan sebanyak 40,00 persen. Apabila dilihat berdasarkan usia, mayoritas responden berusia $>42-54$ tahun sebesar 44,67 persen, kemudian usia $18-30$ tahun sebesar 10,00 persen, usia > 30 - 42 tahun sebesar 35,33 persen, dan usia > 54-66 tahun sebesar 10,00 persen. Berdasarkan jabatan dapat dilihat bahwa sebanyak 135 orang 
dengan persentsae sebesar 90,00 persen merupakan pemilik usaha dan sebanyak 15 orang dengan persentase sebesar 10,00 persen merupakan pengelola usaha.

Studi ini menggunakan dua tahap pendekatan untuk mengukur model sebelum digunakan untuk pengujian hipotesis, bertujuan untuk memverifikasi validitas dan reliabilitas suatu model penelitian. Pertama dengan menganalisis convergent validity dilanjutkan dengan menganalisa discriminant validity.

Uji outer model dilakukan untuk memastikan indikator penelitian layak untuk digunakan sebagai perannya dalam pengukuran variabel penelitian, maka untuk melihat apakah suatu model valid untuk menjadi landasan penelitian maka terdapat tiga kriteria yang harus terpenuhi, yaitu: (1) semua indicator loading harus diatas 0,65 (2) Composite Realibility (CR) harus diatas 0,8, dan (3) Average Variance Extracted (AVE) untuk setiap konstruk harus melebihi angka 0,5 .

Tabel 2. Hasil Ukuran Model

\begin{tabular}{|c|c|c|c|c|}
\hline Konstruk & Indikator & $\begin{array}{c}\text { Outer } \\
\text { Loading }\end{array}$ & $\begin{array}{l}\text { Composite } \\
\text { Reliability } \\
\end{array}$ & $\begin{array}{c}\text { Average Variance } \\
\text { Extracted (AVE) }\end{array}$ \\
\hline \multirow{4}{*}{ Kemitraan pelanggan (X1) } & $\mathrm{X} 1.1$ & 0,776 & \multirow{4}{*}{0,896} & \multirow{4}{*}{0,684} \\
\hline & $\mathrm{X} 1.2$ & 0,817 & & \\
\hline & $\mathrm{X} 1.3$ & 0,856 & & \\
\hline & $\mathrm{X} 1.4$ & 0,857 & & \\
\hline \multirow{4}{*}{ Kemitraan pemasok (X2) } & $\mathrm{X} 2.1$ & 0,851 & \multirow{4}{*}{0,912} & \multirow{4}{*}{0,723} \\
\hline & $\mathrm{X} 2.2$ & 0,830 & & \\
\hline & $\mathrm{X} 2.3$ & 0,861 & & \\
\hline & $\mathrm{X} 2.4$ & 0,858 & & \\
\hline \multirow{3}{*}{ Kemitraan pesaing (X3) } & $\mathrm{X} 3.1$ & 0,852 & \multirow{3}{*}{0,898} & \multirow{3}{*}{0,746} \\
\hline & X3.2 & 0,906 & & \\
\hline & $\mathrm{X} 3.3$ & 0,832 & & \\
\hline \multirow{9}{*}{ Relational quality (Y1) } & Y1.1 & 0,861 & \multirow{9}{*}{0,884} & \multirow{9}{*}{0,515} \\
\hline & Y1.2 & 0,890 & & \\
\hline & Y1.3 & 0,881 & & \\
\hline & Y1.4 & 0,878 & & \\
\hline & Y1.5 & 0,743 & & \\
\hline & Y1.6 & 0,877 & & \\
\hline & Y1.7 & 0,654 & & \\
\hline & Y1.8 & 0,653 & & \\
\hline & Y1.9 & 0,627 & & \\
\hline \multirow{3}{*}{ Kapabilitas Inovasi (Y2) } & Y2.1 & 0,880 & \multirow{3}{*}{0,822} & \multirow{3}{*}{0,614} \\
\hline & Y2.2 & 0,571 & & \\
\hline & Y2.3 & 0,862 & & \\
\hline \multirow{3}{*}{ Kinerja keuangan (Y3) } & Y3.1 & 0,925 & \multirow{3}{*}{0,859} & \multirow{3}{*}{0,675} \\
\hline & Y3.2 & 0,866 & & \\
\hline & Y3.3 & 0,647 & & \\
\hline \multirow{3}{*}{ Kinerja non Keuangan (Y4) } & Y4.1 & 0,779 & \multirow{3}{*}{0,854} & \multirow{3}{*}{0,661} \\
\hline & Y4.2 & 0,860 & & \\
\hline & Y4.3 & 0,797 & & \\
\hline
\end{tabular}

Sumber: Data diolah, 2021

Berdasarkan Tabel 2 menunjukkan bahwa hamper semua outer loading indikator memiliki nilai pada rentang di antara 0,627 hingga 0,906 artinya berada pada batas rekomendasi, selanjutnya nilai Composite Reliability (CR) berada pada rentang antara 0,822 hingga 0,912 yang semuanya berada diatas 0,8 artinya semua konstruk yang dibentuk memiliki konsistensi yang baik sebagai model penelitan, yang ketiga adalah nilai Average 
Variance Extracted (AVE) dimana semuanya bernilai diatas 0,5 yaitu dengan rentang dari 0,515 hingga 0,746 sehingga dapat disimpulkan model penelitian pada studi ini memiliki validitas yang baik.

Untuk mengevaluasi discriminant validity, suatu model penelitian disarankan untuk memastikan bahwa nilai akar Average Variance Extracted (VAVE) sebuah variabel laten harus lebih besar.

\section{Tabel 3. Korelasi Antar Variabel Laten}

\begin{tabular}{lccccccc}
\hline Konstruk & $\begin{array}{c}\text { Kemitraan } \\
\text { pelanggan }\end{array}$ & $\begin{array}{c}\text { Kemitraan } \\
\text { pemasok }\end{array}$ & $\begin{array}{c}\text { Kemitraan } \\
\text { pesaing }\end{array}$ & $\begin{array}{c}\text { Relational } \\
\text { quality }\end{array}$ & $\begin{array}{c}\text { Kapabilitas } \\
\text { inovasi }\end{array}$ & $\begin{array}{c}\text { Knerja } \\
\text { keuangan }\end{array}$ & $\begin{array}{c}\text { Kinerja } \\
\text { non } \\
\text { keuangan }\end{array}$ \\
\hline $\begin{array}{l}\text { Kemitraan } \\
\text { pelanggan }\end{array}$ & 1,000 & 0,488 & 0,326 & 0,432 & 0,494 & 0,320 & 0,183 \\
\cline { 2 - 7 } $\begin{array}{l}\text { Kemitraan } \\
\text { pemasok }\end{array}$ & 0,488 & 1,000 & 0,414 & 0,466 & 0,498 & 0,412 & 0,281 \\
\cline { 2 - 8 } $\begin{array}{l}\text { Kemitraan } \\
\text { pesaing }\end{array}$ & 0,326 & 0,414 & 1,000 & 0,411 & 0,400 & 0,336 & 0,201 \\
$\begin{array}{l}\text { Relational } \\
\text { Quality }\end{array}$ & 0,432 & 0,466 & 0,411 & 1,000 & 0,684 & 0,740 & 0,460 \\
$\begin{array}{l}\text { Kapabilitas } \\
\text { Inovasi }\end{array}$ & 0,494 & 0,498 & 0,400 & 0,684 & 1,000 & 0,762 & 0,521 \\
$\begin{array}{l}\text { Kinerja } \\
\text { Keuangan }\end{array}$ & 0,320 & 0,412 & 0,336 & 0,740 & 0,762 & 1,000 & 0,551 \\
$\begin{array}{l}\text { Kinerja Non } \\
\text { Keuangan }\end{array}$ & 0,183 & 0,281 & 0,201 & 0,460 & 0,521 & 0,551 & 1,000 \\
\hline
\end{tabular}

Sumber: Data diolah, 2021

Model struktural berfokus kepada hubungan yang dihipotesiskan atau jalur antar variabel laten. Adapun hasil dari pengujian inner model dapat dilihat pada Gambar 2.

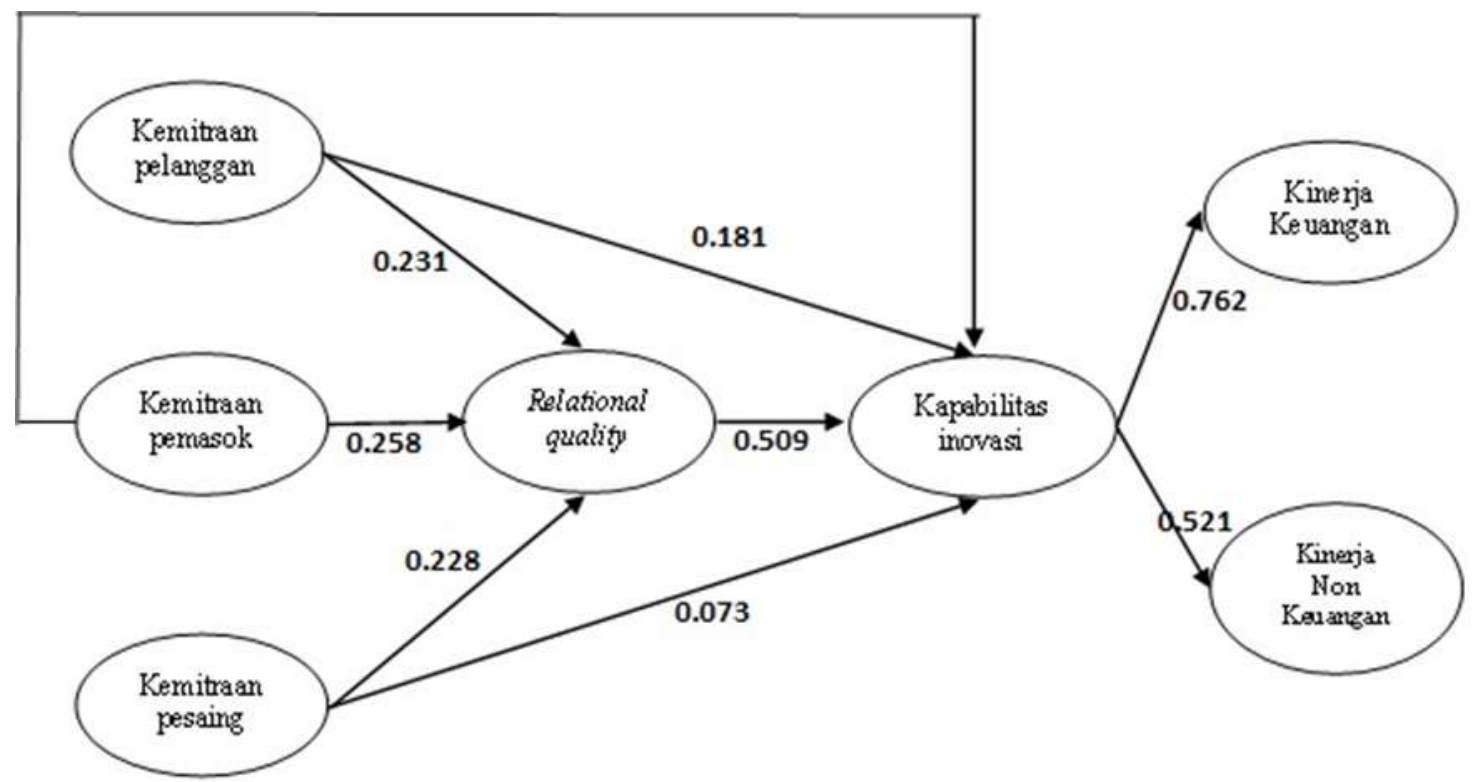

\section{Gambar 1. Model Struktural}

Pada penelitian ini akan dilakukan bootstrap yang akan menghasilkan dua pengukuran model struktural yaitu: nilai $\mathrm{t}\left(t\right.$-test) dan $\mathrm{R}^{2}$ yang akan diinterpretasikan sama seperti analisis regresi berganda (multiple regression) pada umumnya. Kekuatan prediksi suatu model 
penelitian dapat dilihat dengan melihat nilai $\mathrm{R}^{2}$ yang dihasilkan oleh proses bootsrap, pada Tabel 4. disajikan nilai $\mathrm{R}^{2}$ untuk setiap variabel eksogen yang terdapat pada model.

Tabel 4. Koefisien Determinasi

\begin{tabular}{lc}
\hline Konstruk & $\mathbf{R}^{\mathbf{2}}$ \\
\hline Relational quality & 0,314 \\
Kapabilitas inovasi & 0,538 \\
Kinerja keuangan & 0,581 \\
Kinerja non keuangan & 0,271 \\
Catatan: hanya variabel endogen (dependen) yang memiliki nilai $\mathrm{R}^{2}$ & \\
\hline Sumber: Data diolah, 2021 &
\end{tabular}

Sumber: Data diolah, 2021

Berdasarkan Tabel 4, dapat dijelaskan nilai $\mathrm{R}^{2}$ tertinggi terdapat pada variabel kinerja keuangan sebesar 0,581 yang dapat diartikan bahwa sebanyak 58,1 \% variabel kinerja keuangan dapat dijelaskan oleh konstruk yang terdapat pada model yaitu kapabilitas inovasi sedangkan nilai terendah terdapat pada variabel kinerja non keuangan dengan 0,271 yang artinya sebesar 27,1 \% variabel kinerja non keuangan dapat dijelaskan konstruk-konstruk yang mempengaruhi variabel tersebut yakni kapabilitas inovasi. Dari eksaminasi terhadap nilai $\mathrm{R}^{2}$ dapat disimpulkan secara umum kemampuan prediksi model penelitian ini cukup baik, dilihat dari sebagian variabel yang memiliki nilai $\mathrm{R}^{2}$ sama atau diatas 0,50 .

Signifikansi parameter yang diestimasi memberikan informasi yang sangat berguna mengenai hubungan antara variabel-variabel penelitian. Dasar yang digunakan dalam menguji hipotesis adalah nilai yang terdapat pada output path coeficients yang di sajikan pada Tabel 5 .

Tabel 5. Path Coefficient

\begin{tabular}{lccrc}
\hline \multicolumn{1}{c}{ Korelasi antar Variabel } & Koefisien Jalur & t-statistic & P Values & Keterangan \\
\hline Kemitraan.Pelanggan $\rightarrow$ Kapabilitas Inovasi & 0,181 & 2,272 & 0,023 & Diterima \\
\hline Kemitraan.Pemasok $\rightarrow$ Kapabilitas Inovasi & 0,142 & 2,110 & 0,035 & Diterima \\
\hline Kemitraan.Pesaing $\rightarrow$ Kapabilitas Inovasi & 0,073 & 1,154 & 0,248 & Ditolak \\
\hline Kemitraan.Pelanggan $\rightarrow$ Relational Quality & 0,231 & 2,689 & 0,007 & Diterima \\
\hline Kemitraan.Pemasok $\rightarrow$ Relational Quality & 0,258 & 2,800 & 0,005 & Diterima \\
\hline Kemitraan.Pesaing $\rightarrow$ Relational Quality & 0,228 & 2,435 & 0,015 & Diterima \\
\hline Relational Quality $\rightarrow$ Kapabilitas Inovasi & 0,509 & 6,269 & 0,000 & Diterima \\
\hline Kap. Inovasi $\rightarrow$ Kinerja Keuangan & 0,762 & 1,245 & 0,000 & Diterima \\
\hline Kap. Inovasi $\rightarrow$ Kinerja Non Keuangan & 0,521 & 6,384 & 0,000 & Diterima \\
\hline
\end{tabular}

Sumber: Data diolah, 2021

Pengujian hipotesis dilakukan dengan menggunakan $t$-statistics dan melihat $\mathrm{p}$-value. Apabila p-value < 0,05 maka hipotesis diterima. Berdasarkan Tabel 5, dapat dijelaskan bahwa kemitraan pelanggan terhadap kapabilitas inovasi memiliki nilai t-statistik sebesar 2,272 dengan $p$-value sebesar $0,023<0,05$ maka hipotesis diterima. Hal ini berarti bahwa semakin baik kemitraan pelanggan maka semakin tinggi kapabilitas inovasi UKM di Bali. Kemitraan pemasok terhadap kapabilitas inovasi memiliki nilai t-statistik sebesar 2,110 dengan $p$-value $0,035<0,05$ maka hipotesis diterima. Hal ini berarti bahwa semakin baik kemitraan pemasok maka semakin tinggi kapabilitas inovasi. Kemitraan pesaing terhadap kapabilitas inovasi memiliki nilai t-statistik sebesar 1,154 dengan p-value 0,248>0,05 maka hipotesis ditolak. Hal ini berarti bahwa semakin baik kemitraan dengan pesaing maka tidak mampu meningkatkan kapabilitas inovasi. Selanjutnya, kemitraan pelanggan juga berpengaruh terhadap relational quality dengan nilai t-statistic sebesar 2,689 dengan $p$-value sebesar 0,007 $<0,05$ maka hipotesis diterima; kemitraan dengan pemasok juga berpengaruh terhadap 
relation quality dengan nilai t-statistic sebesar 2,800 dengan $p$-value sebesar 0,005 $<0,05$ maka hipotesis diterima; kemitraan pesaing juga berpengaruh terhadap relation quality dengan nilai t-statistic sebesar 2,435 dengan p-value sebesar 0,015 $<0,05$ maka hipotesis diterima. Selanjutnya, relational quality berpengaruh positif dan signifikan terhadap kapabilitas inovasi dengan nilai t-statistik sebesar 6,269 dengan p-value 0,000 $<0,05$ maka hipotesis diterima; kapabilitas inovasi terhadap kinerja keuangan inovasi memiliki nilai tstatistik sebesar 17,245 dengan p-value sebesar 0,000 $<0,05$ maka hipotesis diterima; kapabilitas inovasi terhadap kinerja non keuangan memiliki nilai t-statistik sebesar 6,384 dengan $p$-value sebesar $0,000<0,05$ maka hipotesis diterima.

Uji peran mediasi relational quality pada pengaruh kemitraan stakeholders (kemitraan pelanggan, kemitraan pemasok, dan kemitraan pesaing) terhadap kapabilitas inovasi dengan memeriksa indirect effects yang merupakan output Smart PLS seperti tersaji pada Tabel 6. Berdasarkan Tabel 6, dapat dijelaskan bahwa peran relational quality memediasi pengaruh kemitraan pelanggan terhadap kapabilitas inovasi memiliki nilai t-statistik lebih besar dari nilai t-tabel $(2,476>1,96)$, maka relational quality secara signifikan memediasi kemitraan pelanggan terhadap kapabilitas inovasi. Demikian juga, relational quality mampu memediasi kemitraan pemasok terhadap kapabilitas inovasi karena nilai t-statistik lebih besar dari nilai ttabel $(2,579>1,96)$. Hal yang sama juga ditunjukkan bahwa relational quality mampu memediasi secara signifikan pengaruh kemitraan pesaing terhadap kapabilitas inovasi karena nilai t-statistik lebih besar dari t-tabel $(2,021>1,96)$.

Tabel 6. Indirect Effects

\begin{tabular}{lcccc}
\hline \multicolumn{1}{c}{ Korelasi antar Variabel } & $\begin{array}{c}\text { Koefisien } \\
\text { Jalur }\end{array}$ & t-Statistic & p-Values & Keterangan \\
\hline $\begin{array}{l}\text { Kemitraan pelanggan } \quad(\mathrm{X} 1) \rightarrow \text { Relational } \\
\text { Quality (Y1) } \rightarrow \text { Kapabilitas Inovasi (Y2) }\end{array}$ & 0,118 & 2,476 & 0,014 & Diterima \\
\hline $\begin{array}{l}\text { Kemitraan Pemasok (X2) } \rightarrow \text { Relational } \\
\text { Quality (Y1) } \rightarrow \text { Kapabilitas Inovasi (Y2) }\end{array}$ & 0,131 & 2,579 & 0,010 & Diterima \\
\hline $\begin{array}{l}\text { Kemitraan Pesaing (X3) } \rightarrow \text { Relational Pesaing } \\
(Y 1) \rightarrow \text { Kapabilitas Inovasi (Y2) }\end{array}$ & 0,116 & 2,021 & 0,044 & Diterima \\
\hline
\end{tabular}

Sumber: Data diolah, 2021

Pengaruh Kemitraan Pelanggan Terhadap Relational Quality. Berdasarkan hasil analisis pengaruh kemitraan pelanggan terhadap relational quality diperoleh nilai koefisien beta sebesar 0,231 dengan tingkat signifikansi sebesar 0,007 <0,05 yang berarti Ho ditolak dan $\mathrm{H}_{1}$ diterima. Hasil tersebut berarti, variabel kemitraan pelanggan berpengaruh positif dan signifikan terhadap relational quality. Jadi, semakin baik kemitraan pelanggan yang dibangun oleh UKM di Bali, yang ditunjukkan oleh kemitraan untuk peningkatan kualitas produk, kemitraan untuk memperbaiki desain produk, kemitraan untuk mengupdate teknologi, dan berbagi informasi atau pengalaman maka relational quality semakin baik.

Hasil penelitian ini sekaligus memperkuat hasil penelitian sebelumnya yang dilakukan oleh Huo et al., (2014); Huo et al., (2016); Yu \& Huo (2018), yang menyatakan bahwa variabel kemitraan pelanggan berpengaruh positif dan signifikan terhadap relational quality. Hasil penelitian ini diperkuat oleh penelitian Yu \& Huo (2019), menemukan hasil variable kemitraan pelanggan berpengaruh positif dan signifikan terhadap relational quality sehingga dapat disimpulkan bahwa kemitraan pelanggan memiliki pengaruh yang positif dan signifikan terhadap relational quality, hal ini berarti, dengan semakin baik kemitraan pelanggan yang dibangun pebisnis UKM di Bali maka mampu meningkatkan relational quality yang semakin 
baik juga.

Pengaruh Kemitraan Pemasok terhadap Relational Quality. Berdasarkan hasil analisis pengaruh kemitraan pemasok terhadap relational quality diperoleh nilai koefisien beta sebesar 0,258 dengan tingkat signifikansi sebesar $0,005<0,05$ yang berarti Ho ditolak dan $\mathrm{H}_{1}$ diterima. Hasil tersebut berarti, variabel kemitraan pemasok berpengaruh positif dan signifikan terhadap relational quality. Ini berarti bahwa, semakin baik kemitraan pemasok yang dibangun oleh pebisnis yang ditunjukkan dengan kemitraan untuk meningkatkan kualitas bahan baku, kemitraan untuk mempercepat pengiriman, kemitraan untuk mengupdate teknologi, dan kemitraan untukberbagi informasi maka mampu meningkatkan relational quality.

Hasil penelitian ini sekaligus memperkuat hasil penelitian sebelumnya yang dilakukan oleh Huo et al., (2016); Yu \& Huo (2018), yang menyatakan bahwa kemitraan pemasok memainkan peran penting dalam meningkatkan relational quality. Hasil penelitian tersebut juga diperkuat oleh hasil penelitian dari Yu \& Huo (2019), menemukan bahwa variabel kemitraan pemasok memiliki pengaruh positif dan signifikan terhadap variabel relational quality. Dapat disimpulkan bahwa kemitraan pemasok memiliki pengaruh yang positif dan signifikan terhadap relational quality, hal ini berarti, dengan semakin baik kemitraan pemasok yang dibangun atau dijalin maka relational quality antara UKM dengan pemasoknya juga semakin baik.

Pengaruh Kemitraan Pesaing terhadap Relational Quality. Berdasarkan hasil analisis pengaruh kemitraan pesaing terhadap relational quality diperoleh nilai koefisien beta sebesar 0,228 dengan tingkat signifikansi sebesar 0,015 < 0,05 yang berarti Ho ditolak dan H1 diterima. Hasil tersebut berarti, kemitraan pesaing berpengaruh positif dan signifikan terhadap relational quality. Hal ini berarti, semakin baik kemitraan pesaing yang dijalin oleh UKM di Bali dalam rangka membuat produk baru, mengupdate teknologi, dan berbagi informasi, maka mampu membuat relational quality dengan pesaingnya semakin baik.

Hasil penelitian ini sekaligus memperkuat hasil penelitian sebelumnya yang dilakukan oleh Crick (2019), menyatakan bahwa kemitraan pesaing mampu membuat relational quality dengan pesaing semakin baik; dan Bengtsson et al., (2016), menemukan bahwa kemitraan pesaing berpengaruh positif terhadap relational quality. Dapat disimpulkan bahwa, kemitraan pesaing memiliki pengaruh yang positif dan signifikan terhadap relational quality, hal ini berarti, dengan semakin baiknya kemitraan yang dijalin dengan pesaing maka kualitas hubungan dengan pesaing juga semakin baik.

Pengaruh Kemitraan Pelanggan terhadap Kapabilitas Inovasi. Hasil analisis pengaruh kemitraan pelanggan terhadap kapabilitas inovasi diperoleh nilai koefisien beta sebesar 0,181 dengan tingkat signifikansi sebesar 0,023 < 0,05 yang berarti Ho ditolak dan H1 diterima. Hasil tersebut berarti, kemitraan pelanggan berpengaruh positif dan signifikan terhadap kapabilitas inovasi. Hal ini berarti, semakin baik kemitraan pelanggan yang dijalin maka dapat meningkatkan kapabilitas inovasinya.

Hasil penelitian ini sekaligus memperkuat hasil penelitian sebelumnya yang dilakukan oleh Ngugi et al., (2010, tentang kemitraan pelanggan mampu meningkatkan kapabilitas inovasi. Hasil ini juga diperkuat oleh hasil penelitian Shafi (2020), menemukan hasil bahwa kemitraan pelanggan berpengaruh positif dan signifikan terhadap kapabilitas inovasi. Pengaruh kemitraan pelanggan seperti kemitraan yang dibangun untuk meningkakan kualitas produk, meningkatkan desain produk, mengupdate teknologi dan berbagi informasi sangat 
penting untuk meningkatkan kapabilitas inovasi. Dapat disimpulkan bahwa, kemitraan pelanggan memiliki pengaruh yang positif dan signifikan terhadap kapabilitas inovasi, hal ini berarti, dengan semakin baik kemitraan pelanggan yang dijalin, maka semakin meningkatkan kapabilitas inovasinya.

Pengaruh Kemitraan Pemasok terhadap Kapabilitas Inovasi.Berdasarkan hasil analisis pengaruh kemitraan pemasok terhadap kapabilitas inovasi diperoleh nilai koefisien beta sebesar 0,142 dengan tingkat signifikansi sebesar 0,035 < 0,05 yang berarti Ho ditolak dan H1 diterima. Hasil tersebut berarti, kemitraan pemasok berpengaruh positif dan signifikan terhadap kapabilitas inovasi. Hal ini berarti, semakin baik kemitraan pemasok yang dibangun, maka mampu meningkatkan kapabilitas inovasinya.

Hasil penelitian ini sekaligus memperkuat hasil penelitian sebelumnya yang dilakukan oleh Tu et al. (2014), tentang kemitraan pemasok mampu meningkatkan kapabilitas inovasi; dan Yang \& Shafi (2019), menemukan bahwa kemitraan pemasok berpengaruh positif terhadap kapabilitas inovasi. Hasil ini juga diperkuat oleh hasil penelitian Shafi (2020), menemukan hasil bahwa kemitraan pemasok berpengaruh positif dan signifikan terhadap kapabilitas inovasi.

Pengaruh Kemitraan Pesaing terhadap Kapabilitas Inovasi. Berdasarkan hasil analisis pengaruh kemitraan pesaing terhadap kapabilitas inovasi diperoleh nilai koefisien beta sebesar 0,073 dengan tingkat signifikansi sebesar 0,248 > 0.05, yang berarti Ho diterima dan $\mathrm{H} 1$ ditolak. Hasil tersebut berarti, kemitraan pesaing berpengaruh tidak signifikan terhadap kapabilitas inovasi. Hal ini berarti, semakin baik kemitraan pesaing yang dijalin maka tidak mampu meningkatkan kapabilitas inovasi.

Hasil penelitian ini sekaligus memperkuat hasil penelitian sebelumnya yang dilakukan oleh Shafi (2020), yang menyatakan bahwa kemitraan pesaing tidak mampu meningkatkan kapabilitas inovasi. Hasil yang berlawanan diperoleh oleh Hoffmann et al., (2018), tentang kemitraan pesaing mampu meningkatkan kapabilitas inovasi. Dapat disimpulkan bahwa, kemitraan pesaing tidak memiliki pengaruh positif dan signifikan terhadap kapabilitas inovasi, hal ini berarti, bahwa kemitraan pesaing yang dibangun, tidak mampu meningkatkan kapabilitas inovasi dari UKM di Bali.

Pengaruh Relational Quality terhadap Kapabilitas Inovasi. Berdasarkan hasil analisis pengaruh relational quality terhadap kapabilitas inovasi diperoleh nilai koefisien beta sebesar 0,509 dengan tingkat signifikansi sebesar 0,000 < 0,05 yang berarti Ho ditolak dan H1 diterima. Hasil tersebut berarti, relational quality berpengaruh positif dan signifikan terhadap kapabilitas inovasi. Hal ini berarti, semakin baik relational quality yang tercipta maka dapat meningkatkan kapabilitas inovasi UKM di Bali.

Hasil penelitian ini sekaligus memperkuat hasil penelitian sebelumnya yang dilakukan oleh Heimeriks \& Schreiner (2010), tentang relational quality mampu meningkatkan kapabilitas inovasi. Hasil ini juga diperkuat oleh hasil penelitian Ngugi et al., (2010); Nguyen et al. (2019), menemukan hasil bahwa relational quality berpengaruh positif dan signifikan terhadap kapabilitas inovasi. Pengaruh relational quality seperti komitmen terhadap pelanggan, memuaskan pelanggan, percaya dengan pelanggan, komitmen dengan pemasok, memuaskan pemasok, percaya dengan pemasok, komitmen dengan pesaing, dan percaya dengan pesaing sangat penting untuk meningkatkan kapabilitas inovasi. Dapat disimpulkan bahwa, relational quality memiliki pengaruh positif dan signifikan terhadap kapabilitas inovasi, hal ini berarti, dengan semakin baik relational quality dengan stakeholders, maka semakin meningkatkan kapabilitas inovasi UKM di Bali.

Pengaruh Kapabilitas Inovasi terhadap Kinerja Keuangan. Berdasarkan hasil analisis pengaruh kapabilitas inovasi terhadap kinerja keuangan diperoleh nilai koefisien beta sebesar 
0,762 dengan tingkat signifikansi sebesar 0,000 < 0,05 yang berarti Ho ditolak dan $\mathrm{H} 1$ diterima. Hasil tersebut berarti, kapabilitas inovasi berpengaruh positif dan signifikan terhadap kinerja keuangan. Hal ini berarti, semakin tinggi kapabilitas inovasi yang ditunjukkan oleh UKM di Bali selalu mencoba membua ide produk baru, mencari metode baru, selalu kreatif dalam proses produksi, dan menjadi yang pertama dalam pasar produk baru, maka mampu meningkatkan capaian kinerja keuangan.

Hasil penelitian ini sekaligus memperkuat hasil penelitian sebelumnya yang dilakukan oleh Bahta et al., (2021), tentang kapabilitas inovasi mampu meningkatkan kinerja bisnis. Saunila (2014) tentang kapabilitas inovasi mampu meningkatkan kinerja keuangan; Liao et al., (2020), menemukan bahwa kapabilitas inovasi berpengaruh positif dan signifikan terhadap kinerja bisnis termasuk kinerja keuangan. Dapat disimpulkan bahwa, kapabilitas inovasi memiliki pengaruh yang positif dan signifikan terhadap kinerja keuangan, hal ini berarti, dengan semakin tinggi tingkat kapabilitas inovasi UKM maka kinerja keuangannya juga meningkat.

Pengaruh Kapabilitas Inovasi terhadap Kinerja Non Keuangan. Berdasarkan hasil analisis pengaruh kapabilitas inovasi terhadap kinerja non keuangan diperoleh nilai koefisien beta sebesar 0,521 dengan tingkat signifikansi sebesar $0,000<0,05$ yang berarti Ho ditolak dan $\mathrm{H} 1$ diterima. Hasil tersebut berarti, kapabilitas inovasi berpengaruh positif dan signifikan terhadap kinerja non keuangan. Hal ini berarti, semakin tinggi kapabilitas inovasi yang ditunjukkan oleh selalu kreatif dalam proses produksi, dan menjadi yang pertama dalam pasar produk baru, maka mampu meningkatkan capaian kinerja non keuangan.

Hasil penelitian ini sekaligus memperkuat hasil penelitian sebelumnya yang dilakukan oleh Kafetzopoulos \& Psomas (2015); Simon et al., (2015), tentang kapabilitas inovasi mampu meningkatkan kinerja non keuangan; dan Migdadi (2020), menemukan bahwa kapabilitas inovasi berpengaruh positif dan signifikan terhadap kinerja bisnis termasuk kinerja non keuangan. Dapat disimpulkan bahwa, kapabilitas inovasi memiliki pengaruh yang positif dan signifikan terhadap kinerja non keuangan, hal ini berarti, dengan semakin tinggi tingkat kapabilitas inovasi UKM di Bali maka kinerja non keuangannya juga meningkat.

Peran Relational Quality Memediasi Pengaruh Kemitraan Pelanggan Terhadap Kapabilitas Inovasi. Kemitraan pelanggan yang direfleksikan dengan kemitraan dengan pelanggan untuk berbagi informasi telah terbukti memiliki pengaruh yang positif dan signifikan terhadap relational quality. Begitu juga dengan relational quality yang tercipta baik seperti perusahaan punya komitmen dengan pelanggan, perusahaan memuaskan pelanggan, perusahaan mempercayai pelanggan memiliki pengaruh positif dan signifikan terhadap kapabilitas inovasi. Berdasarkan pengujian hipotesis pada peran relational quality memediasi pengaruh kemitraan pelanggan terhadap kapabilitas inovasi diterima dengan nilai pengaruh total sebesar 0,118 Hal ini mengandung makna bahwa relational quality mampu meningkatkan pengaruh kemitraan pelanggan terhadap kapabilitas inovasi.

Peran Relational Quality Memediasi Pengaruh Kemitraan Pemasok Terhadap Kapabilitas Inovasi. Kemitraan pemasok yang ditunjukkan dengan perusahaan melakukan kemitraan dengan pemasok untuk up-grade teknologi telah terbukti memiliki pengaruh yang positif dan signifikan terhadap relational quality. Begitu juga dengan relational quality yang tercipta baik seperti perusahaan punya komitmen dengan pemasok, perusahaan memuaskan pemasok, dan perusahaan mempercayai pemasok memiliki pengaruh positif dan signifikan terhadap kapabilitas inovasi. Berdasarkan pengujian hipotesis pada peran relational quality memediasi pengaruh kemitraan pemasok terhadap kapabilitas inovasi diterima dengan nilai pengaruh total sebesar $0,131 \mathrm{Hal}$ ini mengandung makna bahwa relational quality mampu meningkatkan pengaruh kemitraan pemasok terhadap kapabilitas inovasi. 
Peran Relational Quality Memediasi Pengaruh Kemitraan Pesaing Terhadap Kapabilitas Inovasi. Kemitraan pesaing yang ditunjukkan dengan telah terbukti memiliki pengaruh yang positif dan signifikan terhadap relational quality. Begitu juga dengan relational quality yang tercipta baik seperti perusahaan memiliki hubungan baik dengan pesaing, memiliki komitmen terhadap pesaing, dan mempercayai pesaing memiliki pengaruh positif dan signifikan terhadap kapabilitas inovasi. Hal ini sesuai dengan penelitian dari Berdasarkan pengujian hipotesis pada peran relational quality memediasi pengaruh kemitraan pesaing terhadap kapabilitas inovasi diterima dengan nilai pengaruh total sebesar 0,116 . Hal ini mengandung makna bahwa relational quality mampu memperkuat pengaruh kemitraan pesaing terhadap kapabilitas inovasi.

Penelitian ini dapat memperkaya konsep hubungan kemitraan pelanggan, kemitraan pemasok, dan kemitraan pesaing dengan kapabilitas inovasi dengan mempertimbangkan variabel relational quality sebagai variabel mediasi dan dampak dari kapabilitas inovasi terhadap capaian kinerja keuangan dan kinerja non keuangan. Demikian juga untuk UKM di Bali ke depan perlu untuk selalu membangun kemitraan dengan stakeholders-nya yang semakin intensif dan baik, sehingga tercipta kualitas hubungan dengan stakeholders yang semakin baik dalam rangka meningkatkan kapabilitas inovasi yang berdampak pada peningkatan kinerja bisnisnya.

\section{SIMPULAN}

Hasil penelitian ini adalah : 1). Kemitraan pelanggan berpengaruh positif dan signifikan terhadap kapabilitas inovasi. Hasil ini berarti bahwa, semakin baik kemitraan pelanggan maka semakin tinggi kapabilitas inovasi. 2). Kemitraan pemasok berpengaruh positif dan signifikan terhadap kapabilitas inovasi. Hasil ini berarti bahwa, semakin baik kemitraan pemasok maka semakin meningkatkan kapabilitas inovasinya. 3). Kemitraan pesaing tidak signifikan terhadap kapabilitas inovasi. Hasil ini berarti bahwa, semakin baik kemitraan pesaing tidak mampu meningkat kapabilitas inovasi. 4). Kemitraan pelanggan berpengaruh positif dan signifikan terhadap relational quality. Hasil ini berarti bahwa, semakin baik kemitraan pelanggan maka semakin tinggi relational quality. 5). Kemitraan pemasok berpengaruh positif dan signifikan terhadap relational quality. Hasil ini berarti bahwa, semakin baik kemitraan pemasok maka semakin meningkatkan relational quality. 6). Kemitraan pesaing berpengaruh positif dan signifikan terhadap relational quality. Hasil ini berarti bahwa, semakin baik kemitraan pesaing maka semakin meningkat relational quality. 7). Relational quality berpengaruh positif dan signifikan terhadap kapabilitas inovasi. Hasil ini menunjukkan bahwa semakin baik relational quality, maka mampu meningkatkan kapabilitas inovasi. 8). Kapabilitas inovasi berpengaruh positif dan signifikan terhadap kinerja keuangan. Hasil ini berarti bahwa, semakin baik kapabilitas inovasi maka semakin meningkat kinerja keuangan. 9). Kapabilitas inovasi berpengaruh positif dan signifikan terhadap kinerja non keuangan. Hasil ini berarti bahwa, semakin baik kapabilitas inovasi maka semakin meningkat kinerja non keuangan. 10). Relational quality secara signifikan memediasi kemitraan pelanggan terhadap kapabilitas inovasi. Dengan kata lain variabel relational quality berfungsi menjembatani pengaruh kemitraan pelanggan terhadap kapabilitas inovasi, namun karena mediasi yang bersifat parsial, maka tanpa adanya relational quality, kemitraan pelanggan masih mampu berpengaruh positif dan signifikan terhadap kapabilitas inovasi. Hasil ini berarti bila kemitraan pelanggan semakin ditingkatkan maka mampu meningkatkan relational quality, dan pada akhirnya 353 
meningkatkan kapabilitas inovasi. 11). Relational quality secara signifikan memediasi kemitraan pemasok terhadap kapabilitas inovasi. Dengan kata lain variabel relational quality berfungsi menjembatani pengaruh kemitraan pemasok terhadap kapabilitas inovasi, namun karena mediasi yang bersifat parsial, maka tanpa adanya relational quality, kemitraan pemasok masih mampu berpengaruh positif dan signifikan terhadap kapabilitas inovasi. Hasil ini berarti bila kemitraan pemasok semakin ditingkatkan maka mampu meningkatkan relational quality, dan pada akhirnya meningkatkan kapabilitas inovasi. 12). Relational quality secara signifikan memediasi kemitraan pesaing terhadap kapabilitas inovasi. Dengan kata lain variabel relational quality berfungsi menjembatani pengaruh kemitraan pesaing terhadap kapabilitas inovasi, namun karena mediasi yang bersifat penuh (full mediation), maka tanpa adanya relational quality, kemitraan pesaing tidak mampu berpengaruh signifikan terhadap kapabilitas inovasi. Hasil ini berarti bila hanya melalui relational quality menjadikan kemitraan pesaing berpengaruh terhadap peningkatan kapabilitas inovasi.

Penelitian ini hanya dilakukan pada UKM berbagai sektor di Bali, sehingga hasil penelitian tidak dapat digeneralisasi pada wilayah yang berbeda. Demikian juga variabel eksogennya hanya kemitraan dengan tiga jenis stakeholders dan ke depan bisa ditambah dengan kemitraan dengan universitas sebagai sumber knowledge dan pihak perbankan sebagai pendukung sumber daya modal, demikian juga dengan variabel mediasi yang digunakan hanya variabel relational quality, sedangkan masih banyak alternatif variabel mediasi lainnya, sehingga ke depan perlu mempertimbangkan variabel mediasi lainnya, seperti kompetensi networking dan manajemen pengetahuan.

\section{REFERENSI}

Akinboade, O. A., \& Kinfack, E. (2012). Regulation, Awareness, compliance and SME Performance in Cameroon's manufacturing and retail sectors. International Journal of Social Economics, 39(12), 1-30. https://doi.org/10.1108/03068291211269073

Al-Wugayan, A. A. A. (2019). Relationship versus customer experience quality as determinants of relationship quality and relational outcomes for Kuwaiti retail banks, International Journal of Bank Marketing, 37(5), 1234-1252. https://doi.org/10.1108/IJBM-09-2018-0251

Anh, N. T. M., Hui, L., Khoa, V. D., \& Mehmood, S. (2019). Relational capital and supply chain collaboration for radical and incremental innovation: An empirical study in China. Asia Pacific Journal of Marketing and Logistics, 31(4), 1076-1094. https://doi.org/10.1108/APJML-10-2018-0423

Aydin, H. (2021). Market orientation and product innovation: the mediating role of technological capability. European Journal of Innovation Management, 24(4), 12331267. https://doi.org/10.1108/EJIM-10-2019-0274

Badawi, N. S., \& Battor, M. (2020). Do social capital and relationship quality matter to the key account management effectiveness?. Journal of Business \& Industrial Marketing, 35(1), 134-149. https://doi.org/10.1108/JBIM-01-2019-0003

Bahta, D., Yun, J., Islam, M. R., \& Ashfaq, M. (2021), Corporate social responsibility, innovation capability and firm performance: evidence from SME, Social Responsibility Journal, 17(6), 840-860. https://doi.org/10.1108/SRJ-12-2019-0401

Bengtsson, M., Raza-Ullah, T., \& Vanyushyn, V. (2016). The coopetition paradox and tension: the moderating role of coopetition capability. Industrial Marketing Management, 53(1), 19-30. https://doi.org/10.1016/j.indmarman.2015.11.008 
Byukusenge, E., Munene, J. C., \& Orobia, L. A. (2021). Managerial competencies and business performance: innovation as a mediator in Rwandan SMEs. International Journal of Law and Management, 63(5), 445-463. https://doi.org/10.1108/IJLMA-092017-0217

Crick, J. M. (2019). The dark side of coopetition: when collaborating with competitors is harmful for company performance. Journal of Business \& Industrial Marketing, 35(2), 318-337. https://doi.org/10.1108/JBIM-01-2019-0057

Crick, J. M. (2020). Unpacking the relationship between a coopetition-oriented mindset and coopetition-oriented behaviours. Journal of Business \& Industrial Marketing, 36(3), 400-419. https://doi.org/10.1108/JBIM-03-2020-0165

Crick, J. M., \& Crick, D. (2020). Coopetition and sales performance: evidence from nonmainstream sporting clubs. International Journal of Entrepreneurial Behavior \& Research, 27(1), 123-147. https://doi.org/10.1108/IJEBR-05-2020-0273

Fawcett, S. E., McCarter, M. W., Fawcett, A. M., Webb, G. S., \& Magnan, G. M. (2015). Why supply chain collaboration fails: the socio-structural view of resistance to relational strategies. Supply Chain Management, 20(6), 648-663. https://doi.org/10.1108/SCM-08-2015-0331

Ferreira, J., \& Coelho, A. (2020). Dynamic capabilities, innovation and branding capabilities and their impact on competitive advantage and SME's performance in Portugal: the moderating effects of entrepreneurial orientation. International Journal of Innovation Science, 12(3), 255-286. https://doi.org/10.1108/IJIS-10-2018-0108

Haber, S., \& Reichel, A. (2005). Identifying performance measures of small ventures-the case of the tourism industry. Journal of Small Business Management, 43(3), 257-286. https://doi.org/10.1111/j.1540-627X.2005.00137.x

Han, S., Lyu, Y., Ji, R., Zhu, Y., Su, J., \& Bao, L. (2020). Open innovation, network embeddedness and incremental innovation capability. Management Decision, 58(12), 2655-2680. https://doi.org/10.1108/MD-08-2019-1038

Heimeriks, K. H., \& Schreiner, M. (2010). Relational quality, alliance capability, and alliance performance: an integrated framework", Sanchez, R. and Heene, A. (Ed.) Enhancing Competences for Competitive Advantage, Advances in Applied Business Strategy, 12, 145-171. https://doi.org/10.1108/S0749-6826(2010)0000012009

Hofer, A. R., Hofer, C., \& Waller, M. A. (2014). What gets suppliers to play and who gets the pay? On the antecedents and outcomes of collaboration in retailer-supplier dyads. The International Journal of Logistics Management, 25(2), 226-244. https://doi.org/10.1108/IJLM-01-2014-0012

Hoffmann, W., Lavie, D., Reuer, J. J., \& Shiplov, A. (2018). The interplay of competition and cooperation. Strategic Management Journal, 39(12), 3033-3052. https://doi.org/10.1002/smj.2965

Hudnurkar, M., \& Rathod, U. (2017). Collaborative practices with suppliers in Indian manufacturing multinationals. Journal of Global Operations and Strategic Sourcing, 10(2), 206-231. https://doi.org/10.1108/JGOSS-07-2016-0022

Huhtala, J.-P., Sihvonen, A., Frösén, J., Jaakkola, M., \& Tikkanen, H. (2014). Market orientation, innovation capability and business performance: Insights from the global financial crisis. Baltic Journal of Management, 9(2), 134-152. https://doi.org/10.1108/BJM-03-2013-0044

Huo, B., Ye, Y., Zhao, X., \& Zhu, K. (2016). Supply chain quality integration: a taxonomy perspective. International Journal of Production Economics, 207, 236-246. https://doi.org/10.1016/j.ijpe.2016.05.004 
Huo, B., Zhao, X., \& Lai, F. (2014). Supply chain quality integration: antecedents and consequences. IEEE Transactions on EngineeringManagement, 61(1), 38-51. https://doi.org/10.1109/TEM.2013.2278543

Kafetzopoulos, D., \& Psomas, E. (2015). The impact of innovation capability on the performance of manufacturing companies: The Greek case. Journal of Manufacturing Technology Management, 26(1), 104-130. https://doi.org/10.1108/JMTM-12-20120117

Kantur, D. (2016). Strategic entrepreneurship: mediating the entrepreneurial orientationperformance link. Management Decision, 54(1), 24-43. https://doi.org/10.1108/MD11-2014-0660

Karakara, A.A.-W., \& Osabuohien, E. (2020). ICT adoption, competition and innovation of informal firms in West Africa: a comparative study of Ghana and Nigeria. Journal of Enterprising Communities: People and Places in the Global Economy, 14(3), 397-414. https://doi.org/10.1108/JEC-03-2020-0022

Khalfallah, M., Ben Salem, A., Zorgati, H., \& Lakhal, L. (2021). Innovation mediating relationship between TQM and performance: cases of industrial certified companies. The TQM Journal. https://doi.org/10.1108/TQM-01-2021-0019

Lacam, J. S., \& Salvetat, D. (2017). The complexity of co-opetitive networks. Business Process Management Journal, 23(1), 176-195. https://doi.org/10.1108/BPMJ-12-20150187

Leite, E., Pahlberg, C., \& Åberg, S. (2018). The cooperation-competition interplay in the ICT industry. Journal of Business \& Industrial Marketing, 33(4), 495-505. https://doi.org/10.1108/JBIM-02-2017-0038

Liao, S., Fu, L., \& Liu, Z. (2020). Investigating open innovation strategies and firm performance: the moderating role of technological capability and market information management capability. Journal of Business \& Industrial Marketing, 35(1), 23-39. https://doi.org/10.1108/JBIM-01-2018-0051

Lu, Q., Deng, Y., Yu, M., Song, H., \& Liu, B. (2021). Supply chain network and financing performance of small and medium enterprises in China: a survey and quasi-replication using fuzzy-set qualitative comparative analysis. Baltic Journal of Management, 16(5), 785-803. https://doi.org/10.1108/BJM-09-2020-0331

Martinez-Conesa, I., Soto-Acosta, P., \& Palacios-Manzano, M. (2017). Corporate social responsibility and its effect on innovation and firm performance: an empirical research in SMEs. Journal of Cleaner Production, 142, 2374-2383. https://doi.org/10.1016/j.jclepro.2016.11.038

Mendoza-ramırez, L., \& Toledo-Lopez, A. (2014). Strategic orientation in handicraft subsistence businesses in Oaxaca, Mexico. Journal of Marketing Management, 30(56), 476-500. https://doi.org/10.1080/0267257X.2014.893248

Migdadi, M. M. (2020). Knowledge management processes, innovation capability and organizational performance. International Journal of Productivity and Performance Management. https://doi.org/10.1108/IJPPM-04-2020-0154

Mokhtarzadeh, N. G., Mahdiraji, H. A., Jafarpanah, I., Jafari-Sadeghi, V., \&Cardinali, S. (2020). Investigating the impact of networking capability on firm innovation performance: using the resource-action-performance framework. Journal of Intellectual Capital, 21(6), 1009-1034. https://doi.org/10.1108/JIC-01-2020-0005

Ngugi, I. K., Johnsen, R. E., \& Erdélyi, P. (2010). Relational capabilities for value co-creation and innovation in SMEs. Journal of Small Business and Enterprise Development, 17(2), 260-278. https://doi.org/10.1108/14626001011041256 
Panno, A. (2019). Performance measurement and management in small companies of the service sector; evidence from a sample of Italian hotels. Measuring Business Excellence, 24(2), 133-160. https://doi.org/10.1108/MBE-01-2018-0004

Paula, I. C. d., Campos, E. A. R. d., Pagani, R. N., Guarnieri, P., \& Kaviani, M. A. (2019). Are collaboration and trust sources for innovation in the reverse logistics? Insights from a systematic literature review. Supply Chain Management, 25(2), 176-222. https://doi.org/10.1108/SCM-03-2018-0129

Saunila, M. (2014). Innovation capability for SME success: perspectives of financial and operational performance. Journal of Advances in Management Research, 11(2), 163175. https://doi.org/10.1108/JAMR-11-2013-0063

Saunila, M., \& Ukko, J. (2012). A conceptual framework for the measurement of innovation capability and its effects. Baltic Journal of Management, 7(4), 355-375. https://doi.org/10.1108/17465261211272139

Shafi, M. (2020). Sustainable development of micro firms: examining the effects of cooperation on handicraft firm's performance through innovation capability", International Journal of Emerging Markets, 16(8), 1634-1653. https://doi.org/10.1108/IJOEM-11-2019-0989

Shou, Y., Shao, J., Chen, A. (2017). Relational resources and performance of Chinese thirdparty logistics providers: The mediating role of innovation capability. International Journal of Physical Distribution \& Logistics Management, 47(9), 864-883. https://doi.org/10.1108/IJPDLM-09-2016-0271

Simon, A., Bartle, C., Stockport, G., Smith, B., Klobas, J. E., \& Sohal, A. (2015). Business leaders' views on the importance of strategic and dynamic capabilities for successful financial and non-financial business performance. International Journal of Productivity and Performance Management, 64(7), 908-931. https://doi.org/10.1108/IJPPM-052014-0078

Tu, C., Hwang, S. N., \& Wong, J. Y. (2014). How does cooperation affect innovation in microenterprises?. Management Decision, 52(8), 1390-1409. https://doi.org/10.1108/MD-07-2013-0388

Windapo, A. O., Olugboyega, O., \& Odediran, S. (2020). Impacts of procurement strategies on construction SMEs' growth. Journal of Financial Management of Property and Construction, 25(3), 423-446. https://doi.org/10.1108/JFMPC-05-2019-0045

Yang, J., Xie, H., Liu, H., \& Duan, H. (2018). Leveraging informational and relational capabilities for performance: An empirical investigation. The International Journal of Logistics Management, 29(3), 985-1000. https://doi.org/10.1108/IJLM-04-2017-0087

Yang, Y., \& Shafi, M. (2019). How does customer and supplier cooperation in microenterprises affect innovation? Evidence from Pakistani handicraft micro-enterprises. Asian Business and Management, 19(5). 1-30. https://doi.org/10.1057/s41291-01900072-4

Yasa, N. N. K., Sukaatmadja, P. G., Jawas, A., Budhi, M. K. S., Marhaeni, A. A. N. (2013). SME performance improvement and its effect on the poverty reduction in Bali. International Jurnal of Business Management Invention, 2(4), 01-12.

Yu, Y., \& Huo, B. (2018). Supply chain quality integration: relational antecedents and operational consequences. Supply Chain Management, 23(3), 188-206. https://doi.org/10.1108/SCM-08-2017-0280

Yu, Y., \& Huo, B. (2019). The impact of relational Capital on supplier quality integration and operational performance. Total Quality Management \& Business Excellence, 30(1112), 1282-1301. https://doi.org/10.1080/14783363.2017.1366265 
Yusof, N., Lai, K. S., \& Marisa, A. (2021). Influences of client focus and company type on innovation and financial performance in the construction industry. Construction Innovation. https://doi.org/10.1108/CI-05-2020-0087

Zacharia, Z., Plasch, M., Mohan, U., \& Gerschberger, M. (2019). The emerging role of coopetition within inter-firm relationships. The International Journal of Logistics Management, 30(2), 414-437. https://doi.org/10.1108/IJLM-02-2018-0021

Zhang, N., Deng, X., Hwang, B.-G., \& Niu, Y. (2020). How to balance interfirm relationships? A case from high-speed railway industry. Journal of Business \& Industrial Marketing, 35(11), 1785-1799. https://doi.org/10.1108/JBIM-09-2019-0389 